\title{
From Apprenticeship to Internship: The Social and Legal Antecedents of the Intern Economy
}

\author{
Alexandre Frenette \\ Arizona State University, Tempe, USA, alexandre.frenette@asu.edu
}

\begin{abstract}
This article looks towards the future of the intern economy by focusing on its past. What led to recent debates about the intern economy? How did it become legally possible for interns to work for free? Using the United States as my case study, I draw parallels between the current intern economy and its closest historical antecedent, the apprenticeship system. By providing a brief overview of the history of work-based learning and the unpaid internship's legal underpinnings, this article ultimately frames current lawsuits and debates as a correction to today's insufficiently scrutinized youth labour regime not unlike the apprenticeship systems of the past. In the attempt to facilitate youth transitions from school to work, yet maintain minimum wage standards, government intervention and-more imminently likely-legal decisions will, I anticipate, eventually transform the intern economy much like the Fitzgerald Act of 1937 drastically formalized apprenticeships in the United States.
\end{abstract}

Keywords: intern economy, internships, apprenticeships, school-to-work, lawsuits, legality

Acknowledgements: I would like to thank the reviewers, special issue editors, Paul Attewell, Michael Crowder, Eric Glatt, and Daniel Jacoby for their helpful comments on this article.

\section{Introduction}

Over the past three years, something surprising yet quite overdue happened in the United States: people became increasingly critical of the intern economy. As the Great Recession exacerbated the plight of the young and the jobless (Shierholz and Edwards 2011), the unpaid internship began drawing the ire of politicians, educators, labour rights activists, as well as students and their worried parents (Greenhouse 2010; Harris 2013; Mosley 2013; Perlin 2011). Before 2010, only a few newspaper articles (mostly op-eds in The New York Times) occasionally questioned the fairness of the intern economy. The only consistent source of critical analysis of the intern economy over the previous decades could be found in legal reviews pondering whether unpaid interns should be considered employees (e.g., Curiale 2010; Gregory 1998; Ortner 1998; Yamada 2002). It is in great part this legal grey area that has brought the intern economy to the forefront as a social issue.

An increasing number of former unpaid interns have been suing companies for back pay (and damages). Two such lawsuits were filed in 2011, seven in 2012, and at least 23 in 2013 (Suen and Brandeisky 2014). The growing public scrutiny of internships escalated in June 2013 when Federal Judge William Pauley handed two unpaid interns, Eric Glatt and Alex Footman, a summary judgment win against Fox Searchlight Pictures. The two ex-interns worked on the film Black Swan and filed a lawsuit against the company in 2011 for violating federal and state labour laws. The judge not only agreed the plaintiffs should be considered employees, but also certified a class action suit on behalf of an entire class of employees (i.e., unpaid interns) at the parent company, Fox Entertainment Group (Greenhouse 2013). Companies, interns, and even the courts appear to be increasingly unclear about how to define and justify a legal unpaid internship. Employers have scrambled to catch up with the threat of litigation, and several companies agreed to pay considerable settlements to former interns, including Viacom ( $\$ 7.2$ million), NBCUniversal ( $\$ 6.4$ million), Condé Nast ( $\$ 5.85$ million), and Warner Music Group (\$4.2 million) (Raymond 2015).

This article looks towards the future of the intern economy by focusing on its past. What led to the recent debates about the intern economy? How did it become legally possible for 
interns to work for free? Using the United States as my case study, I draw parallels between the current intern economy and its closest historical antecedent, the apprenticeship system. By providing a brief overview of the history of work-based learning and the unpaid internship's legal underpinnings, this article ultimately frames current lawsuits and debates as a correction to an insufficiently scrutinized youth labour regime not unlike the apprenticeship systems of the past. In the attempt to facilitate youth transitions from school to work, yet maintain minimum wage standards, government intervention and-more imminently likelylegal decisions will, I anticipate, eventually transform the intern economy much like the Fitzgerald Act of 1937 drastically formalized apprenticeships in the United States.

\section{History of Work-based Learning}

Throughout most of history, teenagers and young adults have engaged in training for occupations via work-based learning opportunities, primarily in the form of apprenticeships. Workbased learning is consistent with the idea of "learning by doing" and can be linked to the larger pedagogical philosophy of experiential education. The idea that a student should learn based on active, situated experience and interaction with the world-in this case the workplace-is often identified with John Dewey's philosophy that life and learning should be integrated: "The inclination to learn from life itself and to make the conditions of life such that all will learn in the process of living is the finest product of schooling" (Dewey 1916, 51). Dewey provided an intellectual argument for experiential learning in The School and Society ([1899] 1956) and The Child and the Curriculum ([1902] 1956), asserting that a child's education must be linked to experience more than abstract thought. However, individuals started learning within work contexts far before Dewey's writings.

The history of work-based learning starts with the apprenticeship and leads to the internship. An apprenticeship is much longer and more educationally ambitious than an internship, usually lasting a few years compared to a few months (or weeks) for internships. Apprenticeships are referred to as the oldest form of training and have been a traditional part of the life cycle at least since the Middle Ages (Rorabaugh 1986). For centuries, apprenticeships have provided a way to train people for crafts and trades, but should also be understood as a complex social and economic system. Apprenticeships have always involved the exchange of training for labour. Skilled masters host apprentices in the workplace for an agreed period of time. Until the 19th century, the relationship between a master and apprentice in some ways resembled the relationship between parent and child. The training provided during an apprenticeship went beyond simply learning a craft or trade. Masters ideally took on the role of parents to serve the apprentices in learning their craft, but also taught them religion and morality (Smith 1981). Apprentices were expected to obey their master much as they would a parent, providing valuable labour as well as loyalty and child-like love. It should be noted that this relationship did not always live up to its ideal form, notably because the relationship was bound by a contract (i.e., indenture) whereby the apprentice served the master for numerous years before earning the right to become a journeyman (Smith 1981).

The arrangement between apprentice and master has varied historically, partly based on era, geography (including local laws and customs), and type of craft or trade. In Keith Snell's (1996) analysis of the apprenticeship as a cultural institution in Britain, he notes a general tendency to group apprenticeship systems into three distinct historical periods: the guild apprenticeship period (12th century to 1563); the statutory apprenticeship period (1563-1814), which was marked by the decrease of guild influence; and the voluntary apprenticeship period (1814-present), where arrangements have come in a variety of forms, often articulated between employers and unions. The key marker between the three periods is the Statute of Artificers from 1563, an Elizabethan enactment that helped formalize the apprenticeship system, though several important clauses were later repealed in 1814. The introduction of the statute brought together the various apprenticeship systems then in existence in England and established their legal standing. The enactment set the length of apprenticeships (usually seven years, as opposed to three to five in countries like France and Germany), limited the number of apprentices in certain trades, prohibited poaching of apprentices by other masters, 
and, in the name of "social order and hierarchy" (Snell 1996, 304), restricted access to profitable trades to the children of masters and owners of certain property. The Statute of Artificers made it statutory for parents to apprentice their sons for craft or agriculture unless they could afford to educate them for a profession. Until 1814, the Statute of Artificers brought considerable formality and legal structure to an apprenticeship system that trained youth (mostly men) employed outside the professions.

Adam Smith was a vocal critic of the then-prevalent 18th-century apprenticeship system, arguing that it served as a mechanism to restrict the supply of workers and confine knowledge to the hands of a select few (Wallis 2008). And yet much like interns today are sometimes limited by a high intern-to-employee ratio, from time to time masters took on more apprentices than desired by their pupils, particularly in those periods and areas where apprenticeship regulation was scarce (Aldrich 1999). Part of Smith's dismay about apprenticeships can be linked to his criticism of guilds, the corporations of masters that (along with local governments) used to regulate apprenticeships. Smith famously portrayed guilds as "a conspiracy against the public" (Epstein and Prak 2008, 1) since they served the masters' interests to the detriment of the economy. Smith's argument about labour market monopsony (i.e., lack of free-flowing labour market) held great weight for some time, though historical research calls for a slightly more nuanced view; it was relatively easy and not uncommon to sidestep restrictions on apprenticeship numbers and the statutory lengths of apprenticeships were sometimes negotiable (Epstein 1998).

Some apprenticeships were better than others, of course, and parents vied to arrange the best possible placement for their children. Since apprenticeships were a crucial mechanism to ensure a child's economic future as well as moral upbringing, parents would give money to masters for some apprenticeships (such as law) while paupers and orphans might end up in less lucrative areas, like farming (Aldrich 1999; Snell 1996). The apprenticeship system Smith criticized has nonetheless been defended as the best solution available during a period noted by the absence of compulsory schooling (Epstein 1998). Yet the apprenticeship system and the institution of enforced indenture did not translate as well in American society.

Apprenticeships thrived in colonial America, a time when the Statute of Artificers mandated the colony's apprenticeship system; however, this institution was organized differently than in Britain. The tradition of guilds never held the same authority in the New World as it did in Europe. In the face of increased demand for skilled workers, colonial America was marked by a scarcity of them. America was a land of settlers in search of opportunity and thus was the site of continual immigration, including that of adult labourers trained elsewhere. America had a considerable rural economy, one where settlers worked their own land. None of these factors were conducive to building strong guilds or otherwise enforcing an indenturedriven apprenticeship system since youth (as well as adults) could usually enter skilled occupations without certification (Elbaum 1989).

An additional reason why apprenticeships did not flourish in America was the country's culture of independence, notably during and after the revolutionary era (Rorabaugh 1986). The rhetoric of independence and belief in governing one's self permeated all aspects of political and economic life, even the deference in status necessary to pursue apprenticeship training. In this way, according to William Rorabaugh (1986), authority based on contractual control weakened the position of masters; apprentices challenged the apprenticeship system that was imported from Britain. Bernard Elbaum's (1989) study of apprenticeships in America supports this reading as he also notes the problem of runaway apprentices; in fact, apprenticeship laws were passed in twelve states between 1783 and 1799 to address this problem, though with very limited effectiveness. By the end of the 18th century, apprenticeships in America became increasingly rare; it seems like the enforcement of written indentures was difficult and ineffective. Youth were therefore trained for occupations much more informally than in previous generations (Elbaum 1989). 


\subsection{From Apprenticeship System to Intern Economy}

In his overview of the apprenticeship system, Ross Perlin $(2011,54)$ praises the Fitzgerald Act (or National Apprenticeship Act) of 1937 because it "finally stabilized and revived apprenticeship in the United States." The Act marks an effort to formalize apprenticeships and stipulates as its goal "to formulate and promote the furtherance of labour standards necessary to safeguard the welfare of apprentices and to cooperate with the States in the promotion of such standards" (50 Stat. 664; 29 U.S.C. 50). Instead of a precursor, others argue that the Act was passed as a reaction to the revival of apprenticeships between 1880 and 1920 (Jacoby 1991). According to this view, apprenticeships were becoming so popular-and the threat of low-paid or unpaid aspiring workers so unwieldy-that this surge led to the passing of the Fitzgerald Act. The Fitzgerald Act is therefore credited by some for limiting apprenticeships to marginal status in the United States, not least because it made training apprentices "prohibitively costly" (Coy 1989, 9). As apprenticeship programs became more formalized they also grew less frequent. In 1920, 2.11 percent of operatives and kindred workers were apprentices, compared to 0.96 percent and 1.01 percent in 1940 and 1950 (Gartner et al, 2006). Nonetheless, Perlin (2011) is correct in portraying the Fitzgerald Act as an example of what well-supervised and planned work-based training can accomplish. The government established standards for apprenticeship programs with the aim for employers to recognize apprentices as employees, and therefore to ensure pay as well as training in crafts and trades deemed "apprenticeable" (U. S. Bureau of Apprenticeship and Training 1964).

By the beginning of the 20th century, America's formal institutions of work-based learning grew beyond the realm of crafts and trades. The apprenticeship model of training remained nearly constant throughout America's history in the form of medical training, though with some variation. Medical schooling shifted from an apprenticeship arrangement to education with little practical content in the early 1800 s, to an educational curriculum incorporating an internship requirement later that century. Medical school eventually was deemed "insufficient preparation" for work and the internship became the norm of American medical training by the 1930s (Thorne 1973). Work-based training gained traction in other fields as well. In 1906, Herman Schneider established the country's first cooperative education program at University of Cincinnati's engineering school, an arrangement Northeastern University emulated in 1909. Cooperative education provides an avenue for students to divide their time between substantive work and classroom learning, yet this and other forms of work-based learning remained marginal until the 1960s.

Work-based learning did not grow in importance in one swift, coordinated movement, but incrementally until the 1990s. The growth and formalization of internships, as with any major change in curriculum, represents a convergence of numerous social forces and the result of larger cultural debates (Rose 2004). An important facilitator for the rise of internships and work-based learning in general has come in the form of government policies. Some ground was set in the 1960s and 1970s pursuant to President Johnson's War on Poverty; tens of millions of dollars were provided to educational institutions to help disadvantaged minorities transition into the workforce via work-based learning programs (Knowles 1975). These policies were coherent with the Coleman Commission report of 1974, which blamed schooling for impeding youth's transition into adulthood because it isolates students from the world of work and contact with adults (Bailey et al. 2004). As James Coleman (1977) also discussed elsewhere, work-based learning provides an opportunity for youth to develop "social maturity" and it can benefit students of diverse backgrounds. However, the political push towards work-based learning in the late 1980s into the 1990s initially focused on a particular population and social problem, i.e., the difficulties of low-income high school graduates (and dropouts) to find employment in their late teens.

"School-to-work" policies of the 1980s financed the establishment of secondary school work-based learning programs (including internships) and, in the early 1990s, a shift in rationale led to postsecondary expansion of these policies in the form of the School-to-Work Opportunities Act of 1994 (Hughes, Bailey, and Mechur 2001). Work-based learning was seen as an educational strategy useful for all students and more than simply training for oc- 
cupations, but also as training through occupations (Bailey et al. 2004). Thomas Bailey, Katherine Hughes, and David Moore (2004) note with irony how work-based learning policies were considered an innovative new strategy to educate and train young adults in the 1990s, although these policy ideas are centuries old. The authors explain this shift as a conjunction of economic and pedagogical developments in the 1980s and 1990s. First, the U.S. appeared to model the School-to-Work Opportunities Act in part based on the apprenticeship systems of their strongest economic competitors, Germany and Japan. During the same time period, constructivist pedagogy and developmental cognitive psychology advocating "learning in context" became increasingly dominant (Bailey et al. 2004). To these two factors should be added a demographic reason for the rise of the intern economy, i.e., the increasing number of college-age youth. During the first decade of the 21 st century, the number of 18to 24 -year olds in the U.S. increased by 11 percent (from 28 to 31.1 million). Simultaneously, the rate of college enrolment among such youth increased from 36 percent in 2001 to 42 percent by 2011 (U. S. Department of Education 2013).

Moreover, the ascent of the internship is consistent with the changing nature of work in the post-industrial era (Beck 2000; Boltanski and Chiapello, 2006; Ross 2003; Sennett 1999). In recent decades, firms have become increasingly flexible and jobs have become less permanent. Arne Kalleberg (2000) and others (Hatton 2011; Hipple 2001; Matusik and Hill 1998) document the rise of "non-standard" work arrangements, i.e., various forms of employment that deviate from the full-time, permanent jobs held more prominently by previous generations (Mills 1951; Whyte 1956). In this context, internships grew as a more purely marketbased regime, as opposed to apprenticeships, which have, to varying extents, been guided or guarded by governments (from local to national), guilds, and unions.

Over the last few decades, what began as a policy (and rhetoric) to facilitate the transition from school to work grew into an unwieldy intern economy where companies welcomed the addition of low-paid or unpaid labour (Frenette 2013). Internships now function as a sorting mechanism and credential system (at least in principle) aimed at rationalizing the transition from school to work, even in occupations that were previously excluded from work-based training schemes. Also, as the Black Swan lawsuit and others attest, interns today are frequently college graduates with no academic affiliation. Nonetheless, the link between higher education and work environments has proved significant in legally justifying the existence of unpaid internships.

\section{History and Legality of Work-based Learning}

According to the Fair Labor Standards Act (FLSA), the 1938 federal legislation regulating employment, interns should be paid. However, this point seems to be a matter of interpretation. An employee is defined in a spectacularly broad way; as Senator Hugo Black put it shortly before the FLSA became law: the definition of an employee is "the broadest definition that has ever been included in any one act" (Curiale 2010, 1539, quoting 81 Congressional Record 7657, 1937). An "employee" is defined as "any individual employed by an employer" and "employ" means "to suffer or permit to work" (29 U.S.C. section 203).

Some exceptions exist to minimum wage laws, notably for "learners," "apprentices," and "handicapped" individuals who, if they meet the defined requirements and the employer applies for special permission, can be paid between 75 percent and 95 percent of the minimum wage. The Wage and Hours Division (WHD) later added the "student-learner" exception for students who are part of a vocational training program, also making this group eligible for this slightly subminimum wage exception (Curiale 2010). Despite these exceptions, the term "employee" remained in need of clarification, which occurred in 1947 when the Supreme Court ruled on Walling v. Portland Terminal Co. (330 U.S. 148), a case opposing railway trainees and a railway company. ${ }^{1}$ To become eligible for employment as railway brakemen, trainees first took part in a program that lasted seven to eight days. Applicants chosen by the company to take part in this program worked with railway yard employees over this period,

\footnotetext{
${ }^{1}$ By this time Hugo Black, who had championed the Black-Connery Bill that eventually became the FLSA, was a Supreme Court judge.
} 
progressing from generally observing activities to doing some work under close supervision (Yamada 2002). Trainees claimed they should be paid minimum wage during their training, but the Supreme Court ultimately disagreed.

The Supreme Court acknowledged that in some instances-though not this one-trainees could be paid 75 percent to 95 percent of the minimum wage under the FLSA, noting:

Without doubt, the Act covers trainees, beginners, apprentices, or learners if they are employed to work for an employer for compensation. This is shown by [section] 14 of the Act, which empowers the Administrator to grant special certificates for the employment of learners, apprentices, and handicapped persons at less than the general minimum wage. The language of this section and its legislative history reveal its purpose. Many persons suffer from such physical handicaps, and many others have so little experience in particular vocations that they are unable to get and hold jobs at standard wages. Consequently, to impose a minimum wage as to them might deprive them of all opportunity to secure work, thereby defeating one of the Act's purposes, which was to increase opportunities for gainful employment. (Walling v. Portland Terminal Co., 330 U.S. 148, 151, 1947)

It is striking how, in the eyes of the law, untrained workers, marked by their youthful inexperience, are akin to people with physical disabilities in their shared inability to find gainful employment. Although the two groups must deal with various prejudices, the law acknowledged as early as 1938 and 1947 the comparative disadvantages of certain workers in the job market. Nonetheless, the Supreme Court found that in some cases a special permit to pay subminimum wages, or even to pay no wages at all, is not necessary according to the spirit of the FLSA:

The definition "suffer or permit to work" was obviously not intended to stamp all persons as employees who, without any express or implied compensation agreement, might work for their own advantage on the premises of another. Otherwise, all students would be employees of the school or college they attended, and as such entitled to receive minimum wages. So also, such a construction would sweep under the Act each person who, without promise or expectation of compensation, but solely for his personal purpose or pleasure, worked in activities carried on by other persons either for their pleasure or profit. (Walling v. Portland Terminal Co., 330 U.S. 148, 152, 1947)

The notion that students doing work at a school cannot claim to be employees is powerful in this case, especially when considering that Portland Terminal Co. trainees were described as students housed by an employer under school-like conditions. The decision further clarifies the intention of the FLSA regarding who is or is not an employee:

The Act's purpose as to wages was to insure that every person whose employment contemplated compensation should not be compelled to sell his services for less than the prescribed minimum wage. The definitions of "employ" and "employee" are broad enough to accomplish this. But, broad as they are, they cannot be interpreted so as to make a person whose work serves only his own interest an employee of another person who gives him aid and instruction. (Walling v. Portland Terminal Co., 330 U.S. 148, 152, 1947)

In this way, the railway brakemen trainees were not deemed to be employees and therefore not subject to further compensation. The 1947 Supreme Court decision cited numerous reasons why these trainees could not be considered employees; for example, the work done through training is to the trainees' benefit. The WHD used much of the same language and reasoning from the Supreme Court ruling to articulate a six-factor test to decide whether a trainee is an employee at a for-profit business:

1. The training, even though it includes actual operation of the facilities of the employer, is similar to that which would be given in a vocational school.

2. The training is for the benefit of the trainees or students.

3 . The trainees or students do not displace regular employees, but work under their close observation. 
4. The employer that provides the training derives no immediate advantage from the activities of the trainees or students, and on occasion his/her operations may actually be impeded.

5. The trainees or students are not necessarily entitled to a job at the conclusion of the training period.

6. The employer and the trainees or students understand that the trainees or students are not entitled to wages for the time spent in training.

(U.S. Department of Labor, Wage and Hour Division 1993, Field Operations Handbook, Section 10b11) ${ }^{2}$

According to the WHD, all six factors must be met in order for a worker to not be considered an employee. In 1982, the Fifth Circuit Court upheld the six-factor test in the all-or-nothing fashion, finding airline trainees not to be employees (Yamada 2002); the same court cited this case and applied identical logic in a 1983 decision (Curiale 2010). However, various courts in the U.S. have applied the six-factor test differently (see Table 1 for sample cases; data drawn from Curiale 2010; Yamada 2002; and court records).

\begin{tabular}{|c|c|c|c|c|}
\hline Case & Court & Year & Context & Ruling \\
\hline $\begin{array}{c}\text { Donovan v. American Airlines Inc. } \\
\text { Atkins v. General Motors Corp. }\end{array}$ & 5th Circuit Court & $\begin{array}{c}1982 \\
1983\end{array}$ & $\begin{array}{c}\text { Flight attendant \& reservation sales agent trainees } \\
\text { State-sponsored program to provide company } \\
\text { with pool of trained workers }\end{array}$ & All-or-Nothing (WHD test) \\
\hline $\begin{array}{c}\text { Tony \& Susan Alamo Foundation } \\
\text { v. Secretary of Labor }\end{array}$ & Supreme Court & 1985 & $\begin{array}{c}\text { Individuals allegedly volunteered for commercial } \\
\text { business of a nonprofit religious organization }\end{array}$ & Economic Reality Test \\
\hline $\begin{array}{c}\text { McLaughlin v. Ensley } \\
\text { Reich v. Parker Fire Prot. Dist. }\end{array}$ & 4th Circuit Court & 1989 & $\begin{array}{c}\text { Trainees/potential workers at snack foods } \\
\text { distribution business }\end{array}$ & Primary Beneficiary Test \\
\hline Archie v. Grand Central Partnership Inc. & 2nd Circuit Court & 1998 & $\begin{array}{c}\text { Formerly homeless individuals sued non-profit; } \\
\text { took part in Pathways to Employment Program }\end{array}$ & Applied all tests above \\
\hline
\end{tabular}

Table 1: Supreme Court \& Circuit Court decisions related to six-factor test

In a 1985 Supreme Court decision, individuals who were allegedly volunteers for the commercial activities of a charity were found to be employees under the Economic Reality Test; according to the court, these individuals carried out activities for which one would usually expect financial compensation (Curiale 2010, 1543). Instead of applying the all-or-nothing six-factor test, the Supreme Court decided that employment status would not depend on isolated factors and it did not matter that volunteers vehemently denied coverage as employees. While a Supreme Court decision could be seen as the final word on the topic, this case is not widely cited in cases regarding trainees or interns, perhaps since it involves the line between volunteer/employee instead of trainee/employee (Curiale 2010). The WHD makes an exception for individuals who volunteer "without expectation of compensation" for non-profits or government entities, and therefore these individuals are not covered under the six-factor test to this day (Yamada 2002; U.S. Department of Labor, Wage and Hour Division 2010, Fact Sheet \#71). Nonetheless, more recent cases involving trainees also interpreted the six-factor test inconsistently.

The Fourth Circuit Court rejected the six-factor test altogether, basing a 1989 decision on the Primary Beneficiary Test, deciding based on who benefits principally between trainee and employer. Similarly, in 1993, the Tenth Circuit Court did not use an all-or-nothing interpretation of the six-factor test, but it did not decide based on the presence or absence of one factor, preferring instead the "Totality of Circumstances" test. The court acknowledged how "the

\footnotetext{
2 The WHD issued Fact Sheet \#71 in April 2010, a clarification of its six-factor test as it applies to interns. The statement updates part one of the six-factor test, specifying that an internship must be similar to training that would be given in an "educational environment" instead of "vocational school" as previously recorded.
} 
expectation of employment upon successful completion of the course" (Yamada 2002, 231) weighed in the trainees' favour, but ultimately decided that firefighter trainees at a firefighting academy were not employees.

Finally, in a decision that noted the lack of consistent interpretation of the six-factor test, the Second Circuit Court applied all of the tests noted above and found that formerly homeless individuals who took part in the Pathways to Employment Program were entitled to minimum wage. The defendants claimed that plaintiffs received counselling and basic skills training so therefore were not entitled to more than the subminimum wage they received, but the court disagreed based on the Economic Reality Test (Curiale 2010).

The line between "student" and "employee" is blurry, even when an intern is paid. In Mayo Foundation for Medical Education and Research et al. v United States, the Supreme Court ruled that medical residents do not fall into a special (tax exempt) "student" category in the Treasury Department's tax regulation since their standing resembles employment more so than an educational activity. This decision (\#09-837, decided January 11, 2011) supports a previous ruling by the Eighth Circuit Court. As a result of the various interpretations of the six-factor test by the courts, there is no clear, legally agreed-upon standard by which to decide if an unpaid intern is an employee.

\section{Conclusion}

As more unpaid interns file lawsuits for back pay and a growing, global intern labour rights movement exerts pressure on companies and governments alike, this article considers the future of the intern economy by highlighting its past. The intern economy is the latest iteration of a millennia-old tradition of work-based learning. Much like apprenticeships were part of a social and economic system marked by guild and state control in lieu of widespread schooling, internships today are greatly facilitated by institutions of higher education as a complement to classroom learning (and, in some cases, a stepping stone to employment). ${ }^{3}$ The contemporary intern economy in the U.S. represents a continuation of the pre-1937 apprenticeship system; both should be understood as complex social and economic systems that (in principle) have involved the exchange of training for labour, aimed to facilitate youth's transition from school to work, and became increasingly formalized over time. However, despite these similarities, the current intern economy operates in a far different context marked by the decline of unions, the rise of non-standard work arrangements, and an environment where "enterprising subjects" (Vallas 2012) must assume the predominant burden of building their employability (Smith 2010) to start and sustain careers.

After a decrease in work-based learning earlier in the 20th century, internships made a considerable ascent due to political, economic, and demographic factors. Nonetheless, the legality of unpaid internships has become a matter of vigorous debate. While the U.S. Department of Labor set guidelines for the educational exception of the FLSA, their six-factor test has been interpreted in several different ways by the courts. No matter which legal interpretation of the six-factor test is applied, as David Yamada (forthcoming) recently concluded, "a good number of unpaid internships-especially in the private sector-run afoul of current federal and state wage and hour laws." Therefore, current lawsuits and debates regarding unpaid internships should be seen as a correction to a legally ambiguous and insufficiently scrutinized youth labour regime not unlike the apprenticeship systems of the past. In the coming years, further legal enforcements will catch up to and alter the internship economy, perhaps as considerably as the Fitzgerald Act or Statute of Artificers transformed apprenticeships.

\section{References}

Aldrich, Richard. 1999. The Apprentice in History. In Apprenticeship: Towards a New Paradigm of Learning, edited by Patrick Ainley and Helen Rainbird, 14-24. London: Kogan Page.

\footnotetext{
${ }^{3}$ Moore (2013) nonetheless notes how internships paradoxically hold a marginal status within postsecondary institutions.
} 
Bailey, Thomas R., Katherine L. Hughes and David T. Moore. 2004. Working Knowledge: Work-based Learning and Education Reform. New York: Routledge.

Beck, Ulrich. 2000. Brave New World of Work. Oxford: Polity/Blackwell.

Boltanski, Luc and Ėve Chiapello. 2006. The New Spirit of Capitalism. London: Verso.

Coleman, James S. 1977. Differences Between Experiential and Classroom Learning. In Experiential Learning: Rationale, Characteristics, and Assessment, edited by Morris T. Keaton, 49-61. Washington, DC: Jossey-Bass Publishers.

Coy, Michael W. 1989. Apprenticeship: From Theory to Method and Back Again. Albany, NY: SUNY Press.

Curiale, Jessica L. 2010. America's New Glass Ceiling: Unpaid Internships, the Fair Labor Standards Act, and the Urgent Need for Change. Hastings Law Journal 61: 1531-1560.

Dewey, John. 1916. Democracy and Education. New York: The Free Press.

Dewey, John. (1899) 1956. The School and Society. Chicago: University of Chicago Press.

Dewey, John. (1902) 1956. The Child and the Curriculum. Chicago: University of Chicago Press.

Elbaum, Bernard. 1989. Why Apprenticeship Persisted in Britain but Not in the United States. The Journal of Economic History 49 (2): 337-349.

Epstein, Stephan R. 1998. Craft Guilds, Apprenticeship, and Technological Change in Preindustrial Europe. Journal of Economic History 53 (4): 684-718.

Epstein, Stephan R. and Maarten Prak. 2008. Introduction. In Guilds, Innovation, and the European Economy, 1400-1800, edited by Stephan R. Epstein and Maarten Prak, 1-24. New York: Cambridge University Press.

Fair Labor Standards Act, 29 U.S.C. Sec. 206.

Frenette, Alexandre. 2013. Making the Intern Economy: Role and Career Challenges of the Music Industry Intern. Work and Occupations 40 (4): 364-397.

Gartner, Scott Sigmund, Michael R. Haines, Alan L. Olmstead, Richard Sutch and Gavin Wright. 2006. Historical Statistics of the United States, edited by Susan B. Carter. New York: Cambridge University Press.

Greenhouse, Steven. 2010. The Unpaid Intern, Legal or Not. The New York Times, April 2. Accessed April 4, 2015. http://www.nytimes.com/2010/04/03/business/03intern.html?ref=stevengreenhouse.

Greenhouse, Steven. 2013. Judge Rules that Movie Studio Should Have Been Paying Interns. The New York Times, June 11. Accessed April 4, 2015.

http://www.nytimes.com/2013/06/12/business/judge-rules-for-interns-who-sued-foxsearchlight.html? $r=1 \&$.

Gregory, David L. 1998. The Problematic Employment Dynamics of Student Internships. Notre Dame Journal of Law, Ethics and Public Policy 12: 227-264.

Harris, Malcolm. 2013. The Unpaid Internship for Credit Must End. Al Jazeera America, November 14. Accessed April 4, 2015. http://america.aljazeera.com/opinions/2013/11/unpaidinternshipscollegecredit.html.

Hatton, Erin. 2011. The Temp Economy: From Kelly Girls to Permatemps in Postwar America. Philadelphia, PA: Temple University Press.

Hipple, Steven. 2001, March. Contingent Work in the Late-1990s. Monthly Labor Review 124, 3-27.

Hughes, Katherine L., Thomas R. Bailey and Melinda J. Mechur. 2001. School-to-Work: Making a Difference in Education. A Research Report to America. New York: Institute on Education and the Economy (IEE), Teachers College, Columbia University.

Jacoby, Daniel. 1991. The Transformation of Industrial Apprenticeship in the United States. The Journal of Economic History 51 (4): 887-910.

Kalleberg, Arne L. 2000. Nonstandard Employment Relations: Part-Time, Temporary, and Contract Work. Annual Review of Sociology 26: 341-365.

Knowles, Asa S. 1975. Cooperative Education: The Catalyst for Innovation and Relevance. Daedalus 104 (1): 202-209.

Matusik, Sharon F. and Charles W. L. Hill. 1998. The Utilization of Contingent Work, Knowledge Creation, and Competitive Advantage. Academy of Management Review 23 (4): 680-697.

Mills, C. Wright. 1951. White Collar. New York: Oxford University Press.

Moore, David T. 2013. Engaged Learning in the Academy: Challenges and Possibilities. New York: Palgrave Macmillan.

Mosley, Ashley. 2013. Why Unpaid Internships Negatively Impact Women. The Huffington Post, December 3. Accessed April 4, 2015. http://www.huffingtonpost.com/ashley-mosley/why-unpaidinternships-negatively-impact-women b 4371987.html.

National Apprenticeship Act, 50 Stat. 664; 29 U.S.C. 50. 
Ortner, Craig J. 1998. Adapting Title VII to Modern Employment Realities: The Case for the Unpaid Intern. Fordham Law Review 66: 2613-2647.

Perlin, Ross. 2011. Intern Nation: How to Earn Nothing and Learn Little in the Brave New Economy. New York: Verso.

Raymond, Nate. 2015. Warner Music to Pay \$4.2 Million to End Intern Wage Lawsuit. Reuters, June 10. Accessed July 6, 2015. http://www.reuters.com/article/2015/06/10/us-warnermusic-lawsuit-internsidUSKBN00Q2KC20150610.

Rorabaugh, William J. 1986. The Craft Apprentice from Franklin to the Machine Age in America. New York: Oxford University Press.

Rose, Mike. 2004. The Mind at Work: Valuing the Intelligence of the American Worker. New York: Viking/Penguin.

Ross, Andrew. 2003. No-Collar: The Humane Workplace and Its Hidden Costs. New York: Basic Books.

Sennett, Richard. 1999. The Corrosion of Character: The Personal Consequences of Work in the New Capitalism. New York: Norton.

Shierholz, Heidi and Kathryn A. Edwards. 2011. The Class of 2011: Young Workers Face a Dire Labor Market Without a Safety Net. Economic Policy Institute. Briefing Paper \#306, April 20.

Smith, Steven R. 1981. The Ideal and Reality: Apprentice-Master Relationships in Seventeenth Century London. History of Education Quarterly 21 (4): 449-459.

Smith, Vicki. 2010. Enhancing Employability: Human, Cultural, and Social Capital in an Era of Turbulent Unpredictability. Human Relations 63 (2): 279-303.

Snell, Keith D.M. 1996. The Apprenticeship System in British History: The Fragmentation of a Cultural Institution. History of Education 25 (4): 303-321.

Suen, Stephen and Kara Brandeisky. 2014. Tracking Intern Lawsuits. ProPublica, April 15. Accessed April 4, 2015. http://projects.propublica.org/graphics/intern-suits

Thorne, Barrie. 1973. Professional Education in Medicine. In Education for the Professions of Medicine, Law, Theology, and Social Welfare, edited by Everett C. Hughes, Barrie Thorne, Agostino M. DeBaggis, Arnold Gurin and David Williams, 17-99. New York: McGraw-Hill Book Company.

U.S. Bureau of Apprenticeship and Training, Department of Labor. 1964. The National Apprenticeship Program.

U.S. Department of Education, National Center for Education Statistics. 2013. Digest of Education Statistics, 2012 (NCES 2014-015), Chapter 3.

U.S. Department of Labor, Wage and Hour Division. 1993. Field Operations Handbook.

U.S. Department of Labor, Wage and Hour Division. 2010, April. Fact Sheet \#71: Internship Programs under the Fair Labor Standards Act. Accessed April 4, 2015. http://www.dol.gov/whd/regs/compliance/whdfs71.pdf.

Vallas, Steven P. 2012. Work: A Critique. Malden, MA: Polity Press.

Walling v. Portland Terminal Co., 330 U.S. 148, 152 (1947).

Wallis, Patrick. 2008. Apprenticeship and Training in Premodern England. Journal of Economic History 68 (3): 832-861.

Whyte, William H., Jr. 1956. The Organization Man. New York: Doubleday Anchor.

Yamada, David C. 2002. The Employment Law Rights of Student Interns. Connecticut Law Review 3; 215-259.

Yamada, David C. Forthcoming. The Legal and Social Movement Against Unpaid Internships. Northeastern University Law Journal.

\section{About the Author}

\section{Alexandre Frenette}

Alexandre Frenette specializes in the study of work, creative industries, and youth labour markets. He earned his Ph.D. in sociology at the Graduate Center, City University of New York (CUNY) in 2014 and is currently a Postdoctoral Scholar at Arizona State University's Herberger Institute for Design and the Arts. Using the music industry as a case study, he is currently working on a monograph about the challenges and the promise of internships as part of higher education, tentatively titled The Intern Economy: Laboring to Learn in the Music Industry. 